\title{
Identification and Validation of CRM Factors on Customer Satisfaction and Loyalty in the Mid-Market Segments of the Hotel Industry
}

\author{
Anand Pd. Sinha, Sanjeev Kr. Srivastava, Rohit Kr. Pandey, Ashok Kr.Asthana
}

\begin{abstract}
Due to fierce competition in the hotel sector, it is essential to initiate and manage long-term and strong relationship to ensure customer satisfaction. The importance of customer relationship is very well identified and accepted by many leading hotel organisations, especially in the global competitive market. Some of the critical CRM elements considered and measured in this study are behaviour of the employees, hospitality management, service quality and relationship management. The hotel business organisation that wish to offer top quality service and gain competitive edge over others, application and implementation of Customer Relationship Management (CRM) programme provides a valuable

opportunity to improve satisfaction and loyalty by increasing customer value. This paper examined the effectiveness of customer relationship management (CRM) elements on customer satisfaction and loyalty. This paper is also to make a framework conceptual model to review identification of factors that analyse the relationship of the customer satisfaction and loyalty through CRM variables by anticipating their expectations and taking course of action within their ability to satisfy needs.
\end{abstract}

Index Terms - Customer Satisfaction, Customer Loyalty. Customer Relationship Management, Hospitality Management, Service Quality.

\section{INTRODUCTION}

In the present market condition, most of the business establishment attempts to manage and develop strong and regular interaction with their customers to ensure maximum customer equity. The effort requires managing effective customer relationship to ensure success in customer satisfaction. The CRM philosophy plays a vital and significant role in the Hotel industry sector, as the fundamental concept of business is based on customer satisfaction through creation of innovative ideas to establish

Manuscript revised on December 19, 2019 and published on December 27, 2019

Anand Prasad Sinha currently working as an Assistant Professor in Department of Management, BIT Mesra, Ranchi.

Sanjiv Kumar Srivastava currently working as an Assistant Professor in Department of Hotel Management, BIT Mesra, Ranchi.

Rohit kumar Pandey is working as Assistant Professor in the department of management, B.I.T Mesra, Ranchi.

Ashok Kumar Asthana currently working as an Assistant Professor in Department of Management, Sarla Birla University, Ranchi, Jharkhand. relationship management. Hotel business follows the principle of is 'guest is always right' and 'guest is like god' (Athiti Devo Bhava). In pursuit to achieve the objective a sincere and continuous effort is imperative for a strong foundation of relationship, which remains the demand of the time Customer satisfaction is a business philosophy which tends to the creation of value for customers, anticipating and managing their expectations, and demonstrating ability and responsibility to satisfy their needs. Qualities of service and customer satisfaction are critical factors for the success of any business [1]. Customer satisfaction is the outcome of customer's perception of the value received in a transaction or relationship, where value equals perceived service quality compared to the value expected from transactions or relationships with competing vendors [2]. To achieve customer satisfaction, it is important to recognize and to anticipate customers' needs and to be able to satisfy them. Enterprises which can rapidly understand and satisfy customers' needs make greater profits than those which fail to understand and satisfy them [3]. Since the cost of attracting new customers is higher than the cost of retaining the existing ones, to be successful managers must concentrate on retaining existing customers implementing effective policies of customer satisfaction and loyalty.

Nowadays one of the biggest challenges for managers in the hotel industry is to provide and sustained customer satisfaction. A customer requirement for quality products and service in the hotel industry has become increasingly evident to professionals [4]. Guest relationships are a strategic asset of the organization [5] and customer satisfaction is the starting point to define business objectives. In this context, positive relationships can create customer's higher commitment and increase their return rate. Long-term and reciprocally advantageous relationships between customers and the hotel are becoming progressively important because of the highly positive correlation between guests' overall satisfaction levels and the probability of their return to the same hotel [6]. Hotels are increasing their investments to improve service quality and the perceived value for guests to achieve better customer satisfaction and loyalty, thus resulting in better relationships with each customer [7]. Relationship quality has a remarkable positive effect on hotel guests' behaviour: it creates positive word of mouth (WOM) and increments repeated guest rates [8]

In the hotel industry, the products and services have become key to success and everlasting competitiveness. Due to fierce competition in the hotel sector, it is essential to initiate and manage a long-term and strong relationship to ensure customer satisfaction. The importance of customer 
relationship is very well-identified and accepted by many leading hotel organisations, especially in the global competitive market. The study examined the effectiveness of customer relationship management (CRM) elements on customer satisfaction and loyalty. Some of the critical CRM elements considered are measured in this study are the behaviour of the employees, hospitality management, service quality and relationship management. The hotel business organisation that wish to offer top quality service and gain a competitive edge over others, application and implementation of Customer Relationship Management (CRM) programme provides a valuable opportunity to improve satisfaction and loyalty by increasing customer value. The study also proposes a framework and review identification of factors that analyse the relationship of the customer satisfaction and loyalty through CRM variables by anticipating their expectations and taking the course of action within their ability responsibly to satisfy needs.

\section{PROBLEM STATEMENT}

The achievement of customer satisfaction is one of the crucial and paramount importance for any organisation. It becomes challenging nowadays as customer needs and expectation are changing all the time due to the advent and growth of Information technology (IT). Customer satisfaction is a purely a personal assessment that is immensely influenced by expectation the customer has. Critical observation revealed that relationship marketing significantly facilitates improved and customised service quality and it's an effective tool and innovative way for improved service that will foster better customer satisfaction by creating new value for their customers. The hotels can move closer to their customer through effective CRM practices and henceforth meeting the ever-changing needs and demands of the customer leading to better customer satisfaction and gaining competitive advantage in the market. Therefore, CRM can facilitate managing customer relationship effectively for long term association through customer satisfaction. In this study, the problem is to explore the impact of CRM on customer satisfaction for attaining more efficiency in relationship with customers in the Mid-Market Segment of the Hotel Industry.

\section{RESEARCH OBJECTIVE}

The research objectives for this study include:

1. To understand the impact of key elements of CRM.

2. To identify various factors related to effectiveness of CRM in customer satisfaction.

3. To propose a suitable CRM framework for customer satisfaction and loyalty.

\section{SCOPE OF THE STUDY}

- Present research work is confined to only the mid-market segment of a state, but its finding applies to the global mid-market segment. The present study has been conducted in selected hotels in the geographical area of Jharkhand.

- The study will also enable the management of the hotel in devising effective business and quality services for improved customer satisfaction and ultimately benefit the customer as well as the management.

\section{LITERATURE OVERVIEW}

Customer satisfaction has become a philosophy for a business organisation that helps to increase customer's value by anticipating their expectations and taking the course of action within their ability responsibly to satisfy needs. For any successful business operation, two essential factors are a very critical quality of service and customer satisfaction [9]. [10], remarked that organisations survive because the customer is there to be served. The critical factor ensuring sustainable advantage depends on high-quality service delivery leading to better customer satisfaction [11]. The satisfaction of the customer is the crucial factors which improve the quality of service for gaining an advantage in the competition and hence the retention of the customer. The satisfaction of the customer is the outcome of the perception about the received value in any exchange or and service quality is the value received in comparison to expected value from exchange or relationships among competing for a service provider [12]. To attain customer satisfaction, therefore it's necessary to apprehend the basic needs and desires of the customer and satisfy them. Organisations that are quick to realise and satisfy customer make more profits as compared to those who are unable to recognize and accomplice [13].As it is expensive to attract a new customer than retaining existing customer successful management should focus on retaining existing customers through the implementation of an efficient strategy for satisfaction of customer as well as loyalty.

Customer satisfaction is the beginning of foundation on which customer loyalty is built. This philosophy enables loyalty's stock for the organization that builds corporate image. The relationship gets consolidated and results in repeated patronage a dissatisfied customer may be the reason for bringing bad reputation to the enterprise. Customer satisfaction is the most significant challenge for the hotel industry. Developing a relationship with customer is an asset for the hospitality establishment [14] and it is the initial stage of origin to decide business objectives. In view of this cordial and positive relationship may facilitate strong commitment from customer and increase retention rate. Continuous and long-term leads to mutual benefit and such beneficial relationships between hotel and the customer is becoming progressively significant as it ensures positive association of relationship and increase in profitability due to increase retention rate [15]. To achieve better customer satisfaction Hotels are investing their major financial portion to improve service quality and the value perception of the guests which leads to intimate relationships with each customer, hence developing loyalty, [16]. The objective of the service provider is not only to satisfy the customer but also try to achieve it more efficiently and effectively over competitors to achieve the organisational goal [17].

The customer-oriented employee behaviour is positively associated to the customer satisfaction and strong commitment towards service provider [18], as employees are considered as internal customer [19] [20]. Employee behaviour lays a foundation of personal relationship demonstrated by individual behaviour at the moment of 
interaction. "High performance is significant for customer satisfaction by exceeding the customer expectation" [21]. A study shows positive experience by customer to good word-of-mouth publicity [22]. Commitment facilitates costumer to make positive comments on the organisation's performance. It is a stage of feelings of belongingness and attachment with an intention of continuing relationship with the service provider. Committed customers are most likely to share information relating to their preference and other personal matters. Customer commitment gives service providers an opportunity to redesign strategy process and final outcomes. It creates an opportunity to target their customers and minimise switching behaviour and foster long-term, continuous and profitable relationships [23].

CRM has significant impact on most organisations to some extent [24]. Trust is the key variable in maintaining relationship commitment and its existence and sustaining ability in relationship depends upon the integrity and reliability of the opposite party. According to him trust is an indispensable element in defining long term desired relationship with a brand loyalty. Trust becomes critical in case of services which are intangible as they are difficult to measure [25]. Customer satisfaction lays the basic foundation to achieve customer loyalty and paving way for a long-term and continuing relationship. It increases the base of loyalty's stock that improves company's image. Strengthening of relationships with guest results in repeat patronage and a dissatisfied customer may be a bad ambassador for the business organisation. Studies concluded by Cherubini, suggests that only $4 \%$ of dissatisfied guest express their grievances to the organisation and explain the cause of their dissatisfaction, while guest who didn't complain officially, make a negative WOM that may involve about 500 people. Investigation on customer satisfaction is an important consideration whether customers will revisit the hotel and suggest others, is the key factor for the successful operation of the hotel business. The present paper helps to evaluate the impact of CRM on customer satisfaction in the Mid-Market Segment of Hotel Industry. The CRM component taken into consideration is as follows:

$>$ Hospitality Management

$>$ Service Quality

$>$ Employee Behaviour

$>$ Relationship Management

$>$ Customer Satisfaction

$>$ Customer Commitment and trust.

$>$ Customer Loyalty

\section{CUSTOMER RELATIONSHIP MANAGEMENT (CRM)}

During 1990s the customer occupied the centre stage of market. The market power was under the control of customer and it was important that they need to be listened for the survival of service provider [26]. In the 20s, the advent and growth of ITs created a platform of opportunities for the customers to acquire information about everything which they need. The knowledge-based information and more awareness of customer, the industries realised the importance of relationship marketing to be successful. According to [27], "customer relationship management is an enterprise strategy necessary to secure a proper, useful and consistent communication with each customer irrespective of the means of communication." While [28], defines "customer relationship management is a process by which to obtain enough information about the existing customers, use this information for incentive of the sales to be repeated, and enable a relationship that will be continuous." The main objective of CRM is to build customer loyalty through identification, attraction and management of long term and continuing relationship with the potential customers. The association of the term relationship along with the word marketing implies a sense of belongingness with a customer or service provider [29] [29]. The philosophy of CRM is based on the principle of foundation of learning relationship with individual customer. Such bonding facilitates better insights of customer about their needs and expectations. Study has revealed that CRM leads to both intangible and tangible benefits for hotel industry along with customer satisfaction [30]. Customer focussed behaviour and maximising customer value increase customer satisfaction and keep the customer loyal [31] and the organisation having better, and deeper customer insight will have competitive edge over the market and customer retention. Further, effective communication and customer care plays an important role in establishing relationship quality supporting customer satisfaction [32].

\section{CONCEPTUAL FRAMEWORK}

A carefully constructed questionnaires and with the help of literature review, the following conceptual proposed model is described to investigate and examine the impact of CRM variables on customer satisfaction leading to customer loyalty.

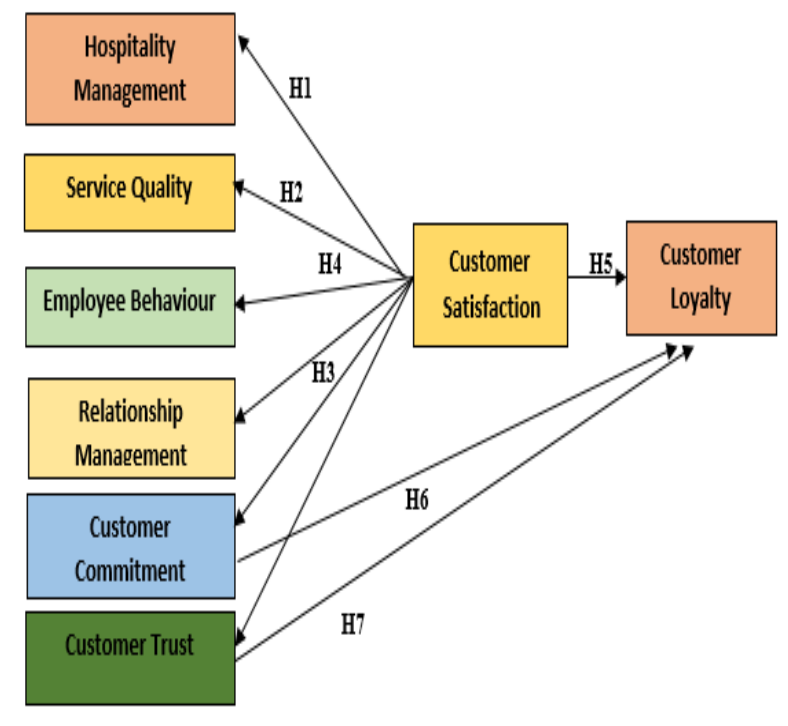

Figurel: Conceptual Framewrork Model

\section{HYPOTHESIS OF THE STUDY}

Following hypotheses are formulated on the basis of developed conceptual framework.

H1: Hospitality Management has no significant relationship with Customer Satisfaction in the hotel industry. 
$\mathbf{H}_{2}$ : Service quality has no significant relationship with Customer Satisfaction in the hotel industry.

H3: Relationship Management has no significant relationship with Customer Satisfaction the in hotel industry.

H4: Employee Behaviour has no significant relationship with Customer Satisfaction the in hotel industry.

H5: Customer Satisfaction has no significant relationship with Customer Loyalty in the hotel industry.

H6: Customer Commitment has no significant relationship with Customer Loyalty in the hotel industry.

H7: Customer Trust has no significant relationship with Customer Loyalty in the hotel industry.

\section{RESEARCH METHODOLOGY}

Research Methodology comprised of structured questionnaire designed to measure the variables of CRM, customer satisfaction, trust, commitment and loyalty. The questionnaire was submitted at the front desk by visiting the hotels personally. As the state Jharkhand is a mid-segment market, most of the hotels are medium sized i.e. 3 star and 4-star category. The information about the hotels were collected from the tourism department of the state and from its web site. The study was conducted in the mid-segment market as it there is tough competition in the present market, and they are most innovative in CRM application [33].

\section{RESEARCH DESIGN}

The present study is based on both exploratory and descriptive analysis. The aim of exploratory study was to make precise and in-depth investigation about the implementation and effectiveness of various dimensions of CRM from operational point in the hotels. The hypothesis testing was done using the regression weights of respective relationships at significance level of 0.05. All these tests were analyzed with the help of Statistical Package for the Social sciences (SPSS) and AMOS 22.

\section{SAMPLE DESIGN}

The study included various cities of Jharkhand state i.e. Ranchi (5 Hotels), Jamshedpur (3 Hotels), Bokaro (2 Hotels), Dhanbad (2 Hotels) and Deogarh (3 Hotels) were identified for the study. Random sampling technique was used for the identification of hotels. The size of the sample for the present study was calculated by the formula,

$\mathrm{n}=(\mathrm{ZS} / \mathrm{E})^{2}$, Where, $\mathrm{Z}$ score is the value corresponding to confidence level.S is the standard deviation; $\mathrm{E}$ is the error value.

$\mathrm{Z}=1.96$ at $95 \%$ confidence level

$\mathrm{S}=0.6$ (based on past consumer studies)

$\mathrm{E}=0.06$ (margin of error is considered as $6 \%$ )

$\mathrm{n}=1.96 \times 1.96 \times 0.6 \times 0.6 / 0.06 \times 0.06$.

The questionnaire was distributed to 750 guests, through reception desk of the hotel. Guests were asked to submit the filled questionnaire in a sealed envelope to the desk as per their convenience. 585 filled questionnaire forms were retrieved out of which 85 forms were rejected due to incomplete answer and some errors. Finally, 500 usable questionnaires i.e. $66 \%$ were retrieved and considered for further analysis. The questionnaires were delivered personally to the participants to ensure the maximum possibility of response rate. The respondents were asked to mark on the Likert Scale from 1 to 5 from Strongly Disagree to Strongly Agree. The study included both primary and secondary data, and structured standard questionnaire was used. Various books, annual reports, internet, journals and other sources are used for collection of secondary data.

\section{ANALYSIS AND INTERPRETATION}

Regression Model - I

Dependent variable $\boldsymbol{Y}=$ Customer satisfaction Independent variables:

$\mathrm{X}_{1}=$ Hospitability Management, $\mathrm{X}_{2}=$ Service Quality, $\mathrm{X}_{3}=$ Employee Behaviour, $\mathrm{X}_{4}=$ Relationship Management Input Data set consisting of 500 observations. Regression equation obtained from the Analysis is: Customer Satisfaction $=0.914$ +0.082 (Hospitability Management) + 0.410 (Service Quality) + 0.175 (Employee Behaviour) + 0.168 (Relationship Management) $Y=0.917+0.082 X_{1}+0.410 X_{2}+0.175 X_{3}+0.168 X_{4}$

Table No. 1

Model Summary

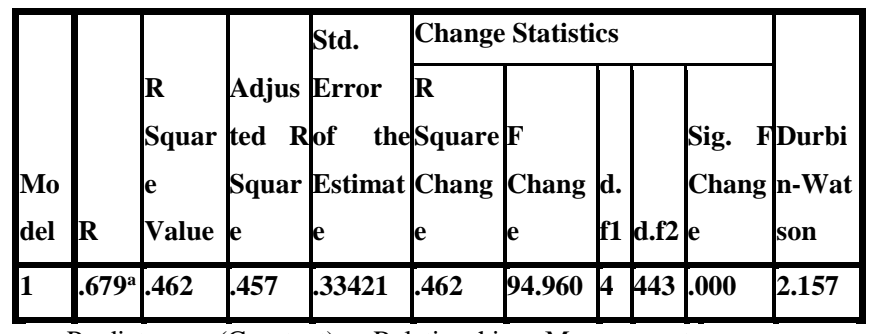

a. Predictors: (Constant), Relationship Management, Hospitality Management, Employee Behavior, Service Quality

b. Dependent Variable: Cusomer

Satisfaction

Table No.2

ANOVA

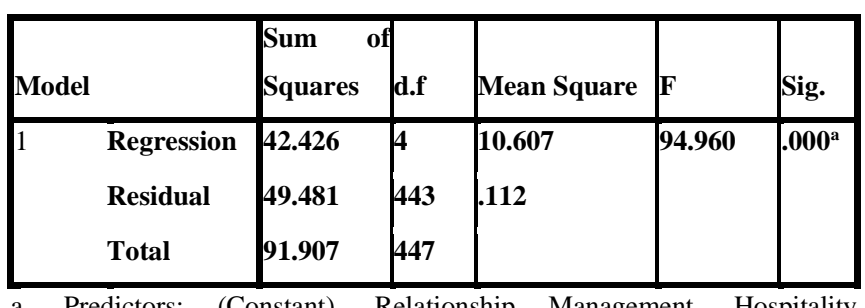

Management, Employee Behaviour, Service Quality

b. Dependent Variable: Customer Satisfaction

Table No.1 (Model Summary) and Table No. 2, (ANOVA), shows that Regression Model is statistically significant. Coefficient of determination, $\mathrm{R}^{2}$ is 0.462 and the value of adjusted $\mathrm{R}^{2}$ is 0.457 , this shows that $46.2 \%$ of regression model is explained by the four independent variables taken together. The impact of multi collinearity is present in the regression model but not significant enough as the difference between $R^{2}$ value and adjusted $R^{2}$ value is .005 that is quite 
insignificant. Durbin-Watson test from the Table no.1 explains that auto correlation effect on the regression is quite insignificant (value of Durbin-Watson test is 2.157, reveals that serial correlation is not present).

Table No.3

Coefficients

\begin{tabular}{|c|c|c|c|c|c|c|}
\hline \multirow{2}{*}{\multicolumn{2}{|c|}{ Model }} & \multicolumn{2}{|c|}{$\begin{array}{l}\text { Unstandardized } \\
\text { Coefficients }\end{array}$} & \multirow{2}{*}{$\begin{array}{c}\begin{array}{c}\text { Standardized } \\
\text { Coefficients }\end{array} \\
\text { Beta }\end{array}$} & \multirow[b]{2}{*}{$\mathbf{T}$} & \multirow[b]{2}{*}{ Sig. } \\
\hline & & B & $\begin{array}{l}\text { Std. } \\
\text { Error }\end{array}$ & & & \\
\hline \multirow[t]{5}{*}{1} & (Constant) & .914 & .184 & & 4.956 & .000 \\
\hline & HM & .082 & .017 & .176 & 4.924 & .000 \\
\hline & SQ & .410 & .043 & .413 & 9.609 & .000 \\
\hline & EB & .175 & .036 & .188 & 4.851 & .000 \\
\hline & RM & .168 & .039 & .180 & 4.326 & .000 \\
\hline
\end{tabular}

Table No.3 for significance of individual independent variable shows that all the variables are statistically significant. The test from the above table reveals that all the parameters of coefficient in the regression model has significant impact on the customer satisfaction. Service quality parameter possesses high positive values followed by Employee Behaviour, Relationship Management and Hospitability Management. Again, t test for all dependent variables obtained is significant, the p-level in the coefficient table is observed to be .000 which suggests that at (Confidence level of 99\%) the significance level of 0.01, all the independent variables are statistically significant in the model. So, the null hypothesis $\mathrm{H}_{1}, \mathrm{H}_{2}, \mathrm{H}_{3}$, and $\mathrm{H}_{4}$ are rejected and it has been concluded that there is a positive and significant impact of Hospitality management, Service quality, Employee behaviour and Relationship management on Customer Satisfaction. Among all the four independent variables, Service quality has significant impact on customer satisfaction followed by employee behaviour, Relationship management and Hospitability management.

\section{Regression Model - II}

\section{Customer Loyalty is the Dependent variable (Y) Independent variables:}

$\mathrm{X}_{1}=$ Customer Satisfaction, $\mathrm{X}_{2}=$ Customer Commitment, $\mathrm{X}$ $=$ Customer Trust Data set consist of 500 observations.

Obtained Regression equation is

Customer Loyalty $=1.941+0.372$ (Customer satisfaction $)+$ 0.055 (Customer commitment) +0.184 (Customer Trust) $\mathrm{Y}=1.941+0.372\left(\mathrm{X}_{1}\right)+0.055\left(\mathrm{X}_{2}\right)+0.184\left(\mathrm{X}_{3}\right)$

Table No.4 Model Summary

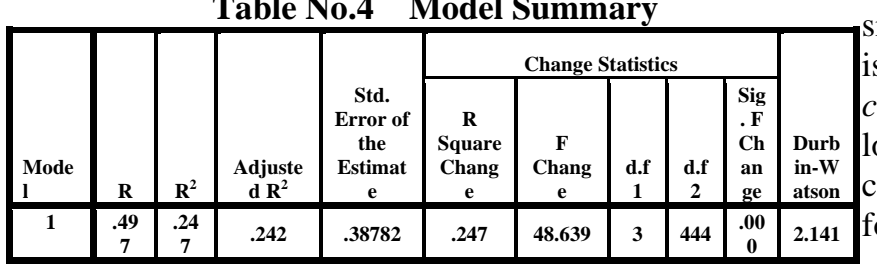

a.Predictors: (Constant), Customer Trust, Customer

Commitment, Customer Satisfaction

b.Dependent Variable:

Customer Loyalty

Table No.5 ANOVA

\begin{tabular}{|l|c|c|c|c|c|}
\hline Model & $\begin{array}{c}\text { Sum of } \\
\text { Squares }\end{array}$ & Df & $\begin{array}{c}\text { Mean } \\
\text { Square }\end{array}$ & F & Sig. \\
\hline
\end{tabular}

\begin{tabular}{|l|l|c|c|c|c|c|}
\hline 1 & Regression & 21.946 & 3 & 7.315 & $\begin{array}{c}48.63 \\
9\end{array}$ & $.000^{\mathrm{a}}$ \\
\cline { 2 - 7 } & Residual & 66.779 & 444 & .150 & & \\
\cline { 2 - 6 } & Total & 88.725 & 447 & & & \\
\hline
\end{tabular}

Table No. 4 (Model Summary) and Table No. 5 (ANOVA) suggests that Regression Model is statistically significant and the $R^{2}$ value is 0.247 and adjusted $R^{2}$ value is 0.242 , shows that $24.7 \%$ of model is explained by the three independent variables, Customer trust, commitment and satisfaction taken together. Again, the multicollinearity impact on regression model is there but it is insignificant as the difference between $\mathrm{R}^{2}$ and adjusted $\mathrm{R}^{2}$ value is .005 which is quite insignificant. Durbin-Watson test reveals that auto correlation effect on the regression is quite insignificant (value of Durbin-Watson test is 2.141), suggests that there is no serial correlation.

\begin{tabular}{|c|c|c|c|c|c|}
\hline \multicolumn{6}{|c|}{ Iable. 10,6 Coefficients } \\
\hline \multirow[b]{2}{*}{ Model } & \multicolumn{2}{|c|}{ Unstandardized Coefficients } & \multirow{2}{*}{$\begin{array}{c}\text { Standaridized Coefficientis } \\
\text { Beta } \\
\end{array}$} & \multirow[b]{2}{*}{ I } & \multirow[b]{2}{*}{ Sige. } \\
\hline & B & Sto Eror & & & \\
\hline (Constant) & 1.941 & .216 & & 8980 & .000 \\
\hline Customer Satisfaction & 372 & .041 & .378 & 9.126 & .000 \\
\hline Customer Commitment & .055 & 0.15 & .150 & 3.632 & .000 \\
\hline Customer Tnust & .184 & .031 & 244 & 5885 & .000 \\
\hline anenendentVanable: Custo & & & & & \\
\hline
\end{tabular}

Table No.6 for significance of individual independent variable shows that all the three independent variables are statistically significant. The test, in the table no. 6, reveals that all the parameters coefficient of regression model has positive impact on the customer loyalty. The parameter customer satisfaction possesses high positive numeric values followed by customer trust and customer commitment. Again, t test for all dependent variables from coefficient table is significant, the observed p-level is .000 suggests that significance level of 0.01 (Confidence level of $99 \%$ ), the independent variable such as customer satisfaction, commitment and trust are statistically significant. So, the null hypothesis $\mathrm{H}_{5}, \mathrm{H}_{6}$, and $\mathrm{H}_{7}$ are rejected. It s concluded that there is a positive and significant impact of customer satisfaction, commitment and trust on customer oyalty. Among all the three independent variables, the impact of customer satisfaction on customer loyalty is most significant followed by customer trust, and customer commitment.

\section{RESULT OF CONCEPTUAL FRAMEWORK MODEL}

It's not essential requirement to achieve all indices for fitness of a report. Some important fit indices obtained from various categories are presented in the paper to acknowledge the overall model fit. Chi-square/degree of freedom $(d . f)$, comparative fit index $(C F I)$, Initial fit index (IFI), goodness 
of fit index $(G F I)$, adjusted goodness of fit index $(A G F I)$ and (RMSEA) Root mean square error of approximation are considered in this study. The chi-square $\left(\chi^{2}\right)$ identifies that statistics of null hypothesis to ensure that the data fits the model. The value of $\chi^{2}$ divided by the degree of freedom (df) should be less than 2 and is supposed to be appropriate and assumed as the first fit criteria in the measurement technique. The $\chi 2$ value of Customer satisfaction model in this study was 41.899 as shown in the table no.7 (d.f $=13)$, and $\chi 2 / \mathrm{df}$ is $=3.223$, p-value $=.000$ suggest that the model fits the data, it is statistically significant.

Table No.7 CMIN

\begin{tabular}{|l|c|c|c|c|c|}
\hline Model & NPAR & CMIN & DF & P & CMIN/DF \\
\hline $\begin{array}{l}\text { Default } \\
\text { model }\end{array}$ & 31 & 41.899 & 13 & .000 & 3.223 \\
\hline $\begin{array}{l}\text { Saturated } \\
\text { model }\end{array}$ & 44 & .000 & 0 & & \\
\hline $\begin{array}{l}\text { Independence } \\
\text { model }\end{array}$ & 8 & 319.358 & 36 & .000 & 8.871 \\
\hline
\end{tabular}

Table No.8 Baseline Comparisons

\begin{tabular}{|l|c|c|c|c|c|}
\hline Model & $\begin{array}{c}\text { NFI } \\
\text { Delta1 }\end{array}$ & $\begin{array}{c}\text { RFI } \\
\text { rho1 }\end{array}$ & $\begin{array}{c}\text { IFI } \\
\text { Delta2 }\end{array}$ & $\begin{array}{c}\text { TLI } \\
\text { rho2 }\end{array}$ & CFI \\
\hline Default model & .869 & .637 & .906 & .718 & .898 \\
\hline $\begin{array}{l}\text { Saturated } \\
\text { model }\end{array}$ & 1.000 & & 1.000 & & 1.000 \\
\hline $\begin{array}{l}\text { Independence } \\
\text { model }\end{array}$ & .000 & .000 & .000 & .000 & .000 \\
\hline
\end{tabular}

Table No.9 RMSEA

\begin{tabular}{|c|c|c|c|c|}
\hline Model & RMSEA & $\begin{array}{c}\text { LO } \\
90\end{array}$ & $\begin{array}{c}\text { HI } \\
90\end{array}$ & PCLOSE \\
\hline Default model & .067 & .045 & .090 & .100 \\
\hline $\begin{array}{c}\text { Independence } \\
\text { model }\end{array}$ & .126 & .113 & .138 & .000 \\
\hline
\end{tabular}

The goodness-of-fit statistics is described as incremental or comparative indices of fit. Since NFI (Normed Fit index) shows a tendency of inappropriateness of fitness in small samples but is has proposed Comparative Fit Index (CFI) replacing NFI for small sample size. The values of both NFI and CFI lies between 0 and 1.00 and derived by comparing a hypothesized model with respect to independence (or null) model. Value > .90 is considered to represent a well-fitting model. In this study the value is .898 as shown in the table no.8 indicating the perfect fit of the model. The coefficient value of RFI, NFI and CFI range from 0 to 1.00 , and values close to .95 indicates superior fit. In this study the value of RFI .637 indicating the moderately fit of the model. IFI values that are greater than .90 are regarded as acceptable. The value of IFI in present study is 0.906 and fulfils the model fit as shown in the table no.8.

RMSEA measuring the estimation of discrepancy, expressed the $d f$, and that makes it sensitive towards the number of estimated parameters. According to Browne \& Cudeck, [34], values should lie between .05 and .08. Lower than .05 values show good fit, and values near .08 indicate considerable errors of approximation in the population. Mac Callum et al. [35] stressed that RMSEA values ranging between .08 and .10 explains mediocre fitness, and values more than .10 represents poor fit. Though $\mathrm{Hu}$ and Bentler [36] suggested the value of RMSEA of .06 is a good fit between the observed data and hypothesized model. In this case, the value of RMSEA is 0.067 as shown in the table no.9. which indicate good fit of model. As the values of most of the parameters estimates are positive and significant baring a few those are not significant it suggests that the model fits the data moderately and is an acceptable model.

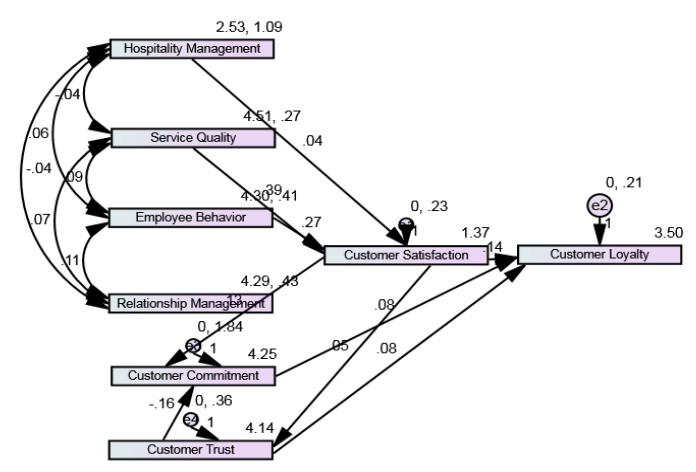

Figure2: Conceptual Framework Model

\section{CONCLUSIONS}

The finding reveals that the variable of CRM has significant association and relationship with customer satisfaction and loyalty. Many variables do not have high positive significant impact on the dependent variables. Employee behaviour, relationship management and service quality impact significantly on customer satisfaction and building relationship with customer evidently contributes significantly in increasing customer loyalty. The hotels must emphasize the three CRM variables for better business performance to increase profitability through enhanced satisfaction leading to customer loyalty. The employee should be polite and courteous while dealing with customer. They need to acquire good communication skills to make and manage relationship and develop intimacy. It is also imperative and emphasized that as employees' behaviour, service quality and relationship management are indispensable for managing customer loyalty management should make serious effort and consider training for employees to develop skills and art of expressing themselves to respond and meet customers' needs and expectation. If hotels business pays serious attention on customer 
satisfaction, it will enable them to respond at faster rate to changing market trends, increase stock of loyalty. The survey has depicted a picture that the respondents understand the customer relationship value and smart enough to realise about the fulfilment of their needs. The study showed that relationship marketing enhances customer value and is a key element for gaining customer loyalty. Since all the hypotheses were confirmed, the research outcome provides hotel management with various dimensions of customer relationship marketing strategies may be applied to gain customer loyalty. The outcome of the study helps the management not only to understand potential guest needs and act to meet them profitably, but also guides them to cope up with the changing needs of the guest.

\section{REFERENCES}

[1] Gronoos, C. "Service Management and Marketing", A Customer Relationship Management Approach (2nd ed.). Chichester: Wiley. 1990.

[2] Blanchard, R. F. \& Galloway, R. L. "Quality in Retail Banking, International Journal of Service Industry Management”, 5(4), 5-23. 1994.

[3] Barsky J., \& Nash L. 'Customer Satisfaction': Applying Concepts to Industry- Wide Measures".The Cornell Hotel and Restaurant Administration Quarterly, 44 (4), 173-183.2003.

[4] Lam T., \& Zhang H. (1999). Service Quality of Travel Agents: The Case of Travel Agents In Hong Kong. Tourism Management, 20, 341-349. 1999.

[5] Gruen, T. W., Summers, J. O. \& Aciton, F. Relationship Marketing Activities, Commitment and Membership Behaviours in Professional Associations. Journal of Marketing 64 (3), 34-49.2000

[6] Choi, T. Y. \& Chu, R. (2001). Determination of Hotel Guests' Satisfaction and Repeat Patronage in the Hong Kong hotel industry. International Journal of Hospitality Management, 20, 277-297.2001.

[7] Jones D. L., Mak B., \& Sim J. A New Look at the Antecedents and Consequences of Relationship Quality in the Hotel Service Environment. Services Marketing Quarterly, 28(3), 15-31.2007.

[8] Kim W. G., Han J. S., \& Lee E. Effects of relationship marketing on repeat purchase and word of mouth. Journal of Hospitality \& Tourism Research, 25 (3), 272-288.2001

[9] Parasuraman, A., Zeithaml, V.A. \& Berry, L.L. SERVQUAL: A Multiple Item Scale for Measuring Consumer Perceptions of Service Quality, Journal of Retailing, 64(1), 14-40. 1988.

[10] Valdani E. Cliente \& Service Management, Egea, Milan, 2009.

[11] Shemwell DJ, Yavas U, \& Bilgin Z. Customer- Service Provider Relationships: An Empirical Test of a Model of Service Quality Satisfaction and Relationship. Oriented Outcomes. 9(2),155-168. 1998.

[12] Zeithaml, Valarie A., Lenoard L. Berry, \& A. Parasuraman. The Behavioural Consequences of Service Quality, Journal of Marketing, 60, 31-46. 1996.

[13] Barsky J., \& Nash L. Customer Satisfaction: Applying Concepts to Industry- Wide Measures. The Cornell Hotel and Restaurant Administration Quarterly, 44 (4), 173-183. 2003.

[14] Gruen, T. W., Summers, J. O. \& Acito, F. Relationship Marketing Activities, Commitment and Membership Behaviours in Professional Associations. Journal of Marketing 64 (3), 34-49. 2000.

[15] Choi, T. Y. \& Chu, R. Determination of Hotel Guests' Satisfaction and Repeat Patronage in the Hong Kong hotel industry. International Journal of Hospitality Management, 20, 277-297. 2001.

[16] Jones D. L., Mak B., \& Sim J. A New Look at the Antecedents and Consequences of Relationship Quality in the Hotel Service Environment. Services Marketing Quarterly, 28(3), 15-31. 2007.

[17] Kotler P., Bowen J.T., \& Makens J.C. Marketing for Hospitality and Tourism 5th edition, Pearson. 2010.

[18] Donavan, D. T. \& Hocutt, M. A. Customer evaluation of service employee's customer orientation: extension and application. Journal of Quality Management, 6(2),293-306. 2001.
[19] Gremler, D. D., \& Bitner M. J. The Internal Service Encounter International Journal of Service Industry Management, 5(2), 34-56. 1994.

[20] Emery, C.R., \& Fredendall, L.N. (2002). The Effect of Teams On Firm Profitability and Customer Satisfaction. Journal of ServiceResearch, 4(3), 217-229. 2002.

[21] Zeithaml, Valarie A., Lenoard L. Berry, \& A. Parasuraman. The Behavioural Consequences of Service Quality, Journal of Marketing, 60, 31-46. 1996.

[22] Huston, Ted L. \& Robert L. Burgess. SocialExchange in Developing Relationships An Overview, in Social Exchange in Developing Relationships, Robert L.Burgess and Ted L. Huston, eds. New York:3-28. 1979.

[23] Baker, S. New Consumer Marketing: Managing. A Living Demand System. England: Wiley. 2003.

[24] N'Goala, G. Customer Switching Resistance (CSR): The Effects of Perceived Equity, Trust and Relationship Commitment, International Journal of Service Industry Management, 18(1), 510-533. 2006.

[25] Bozkurt, V...Approaches to Globalisation, Dicle University Ziya Gökalp Faculty of Education Journal, 13 (2009), 1-16. 2000.

[26] Kathleen, K. "Customer Relationship Management: How to Measure Success, Database:Master FILE Premier, Bank Accounting \& Finance (Euro Money Publications PLL), 13(4). 2000.

[27] Odabaşı, Y. "Satışta ve Pazarlamada Müşteri İlişkileri Yönetimi”(CRM) (Customer Relationship Management in Sales and Marketing (CRM)), Izmir, Turkey: Sistem Yayincilik. 2000.

[28] Samiee, S., Chabowski, B.R. \& Hult, G.T.M.International Relationship Marketing: Intellectual Foundations and Avenues for Further Research,Journal of International Marketing, 23(4), 1-21. 2015

[29] Rahimi, R. \& Gunlu, E. Implementing Customer Relationship Management (CRM) In Hotel Industry from Organizational CulturePerspective: Case Of A Chain Hotel In The Uk", International Journal of Contemporary Hospitality Management, (28)1,89, 112. 2016.

[30] Pozza, I. D., Goetz, L. \& Sahut, J. M. Implementation Effects in the Relationship between CRM and its Performance, Journal of Business Research, 89, 391-403. 2018.

[31] Santouridis, I., \& Veraki, A. Customer Relationship Management and Customer Satisfaction: The Mediating Role of RelationshipQuality. Total Quality Management, 28(10), 1122-1133. 2017.

[32] Sahadev, S., \& Islam, N. Why Hotels Adopt Icts: A Study of The Ict Adoption Propensity of Hotels In Thailand. International Journal of Contemporary Hospitality Management, 17(5), 391-401. 2005.

[33] Browne, M. W., \& Cudeck, R. Alternative Ways Of Assessing Model Fit. In K. A. 1993.

[34] Mac.Callum R. C., Browne M. W., \& Sugawara H. M. Power Analysis and Determination of Sample Size for Covariance Structure Modelling. Psychological Methods.1,130-149. 1996.

[35] Bentler P. M., \& Hu, L. "Cut-off Criteria for Fit Indexes in Covariance Structure Analysis: Conventional Criteria versus New Alternatives. Structural Equation Modelling. 6(1), 35-55. 1999. 


\section{AUTHORS PROFILE}

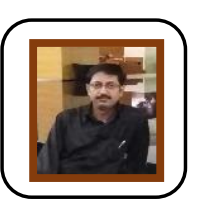

Anand Prasad Sinha currently working as an Assistant Professor in Department of Management, BIT Mesra, Ranchi. He joined as a Sr. Research Associate since 2002 in department of Management, BIT Mesra, Ranchi, assisted Govt Sponsored Project on Department of Scientific and Industrial Research, Ministry of HRD, Govt of India. He has awarded Ph.D. in management from BIT, Mesra. He has several national and international research papers published in reputed and indexed journals, to his credit.

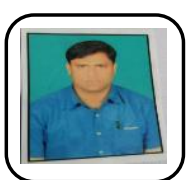

Sanjiv Kumar Srivastava currently working as an Assistant Professor in Department of Hotel Management, BIT Mesra, Ranchi. He has several national and international research papers published in reputed and indexed journals, to his credit.

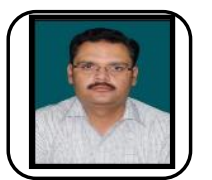

Rohit kumar Pandey is working as Assistant Professor in the department of management, B.I.T Mesra, Ranchi. He has done his doctorate in humanities (English), MBA (Marketing and HR) from B.I.T Mesra and Masters in English from Vinoba Bhave University, Hazaribagh, Jharkhand. He has several publications in refereed journal both national and international in the area of Humanities and Management and has attended various seminar and international conferences. Furthermore, he is actively involved in various activities of the department.

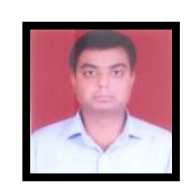

Ashok Kumar Asthana currently working as an Assistant Professor in Department of Management, Sarla Birla University, Ranchi, Jharkhand. He started his career as an Assistant Professor in at New Delhi Institute of Management, since 16 June 2008 to August 2019.

Currently he is Pursing Ph.D. from ICFAI University, Ranchi. He has received "Chairman's Special Appreciation Award" for Best Faculty researcher research in the Year, 2018 and also received "Chairman's Special Appreciation Award" for Writing maximum number of research papers in the Year, January,2016. He has several national and international research papers published in reputed and indexed journals, to his credit. 